\title{
Erratum to: Analysis of the Medicinal and Aromatic Plants Value Chain in Albania
}

\author{
Drini Imami · Alban Ibraliu · Nazim Gruda · Engjell Skreli · Ndoc Fasllia
}

Published online: 9 February 2016

C Springer-Verlag Berlin Heidelberg 2015

\section{Erratum to: Gesunde Pflanzen}

DOI 10.1007/s10343-015-0354-0

The authors were listed in the wrong order in the electronic version of this article. The correct order is: Drini Imami, Alban Ibraliu, Nazim Gruda, Engjell Skreli, Ndoc Fasllia.

The publisher apologizes for this error.

The online version of the original article can be found under doi:10.1007/s10343-015-0354-0

D. Imami $(\bowtie) \cdot$ A. Ibraliu $\cdot$ E. Skreli $\cdot$ N. Fasllia

Faculty of Economics and Agribusiness,

Agriculture University of Tirana,

Tirana, Albania

e-mail:dimami@ubt.edu.al

N. Gruda

University of Bonn,

Bonn, Germany 